\title{
The influence of the calorie content of the diet on the uptake of labelled amino acids by tissue proteins
}

\author{
By H. N. MUNRO, J. CHISHOLM and D. J. NAISMITH \\ Department of Biochemistry, University of Glasgow
}

(Received 4 October I96I-Revised 2 December I96I)

Previous studies (Munro \& Naismith, 1953) show that the response of protein metabolism to changes in calorie intake is determined by the amount of protein in the diet. When rats were given a diet containing an adequate amount of protein but low in energy content, increments in calorie intake from either carbohydrate or fat resulted in a linear improvement in nitrogen balance and an increase in the protein content of the liver. On the other hand, similar changes in the calorie content of a protein-free diet did not have these effects. Although a slight improvement in $\mathrm{N}$ balance resulted from addition of calories in the form of carbohydrate, addition of extra fat did not influence $\mathrm{N}$ balance and neither energy source increased the protein content of the liver. In order to explore the mechanism underlying this difference in the response to changes in calorie intake at the two levels of dietary protein, we have carried out in vitro and in vivo experiments in which the rates of uptake of labelled amino acids by tissue proteins have been related to the protein and calorie content of the diet previously given to the animals.

\section{EXPERIMENTAL}

\section{In vitro studies on amino acid uptake}

In the first series of in vitro experiments, the uptake of $\left[{ }^{35} \mathrm{~S}\right]$ methionine into tissue slices was examined in relation to the calorie content of the preceding diet. Only animals receiving an adequate intake of protein were studied. The results obtained in these experiments were amplified by similar experiments with $\left[{ }^{14} \mathrm{C}\right]$ glycine in which the level of protein intake as well as calorie intake was varied.

Animals and diets. Male albino rats weighing about $25^{\circ} \mathrm{g}$ were housed individually under thermostatic conditions and were given a synthetic diet of the pattern used by Munro \& Naismith (1953) to provide different levels of calorie intake along with either an adequate amount of protein or with none. At ro a.m. the animals were given a basic diet containing $2.8 \mathrm{~g}$ casein, I $\mathrm{g}$ potato starch, $0.5 \mathrm{~g}$ glucose, $0.5 \mathrm{~g}$ fat and $2 \mathrm{~g}$ of a vitamin-mineral-roughage mixture (Munro, 1949). For animals given the protein-free diet, all the casein was replaced by a mixture of equal parts of starch and glucose. At each of these two levels of protein intake the rats were further subdivided into low-calorie and high-calorie intake groups. The basic diets provided daily about $800 \mathrm{kcal} / \mathrm{m}^{2}$ body surface, and animals in the low-calorie intake group received no further food. Rats in the high-calorie intake group were given additional calories in the evening sufficient to raise their total intake to about $1600 \mathrm{kcal} / \mathrm{m}^{2}$.

In the experiments on the in vitro uptake of $\left.{ }^{35} \mathrm{~S}\right]$ methionine into liver and 
diaphragm the high-calorie intake group consisted of animals that were given additional carbohydrate (glucose) or fat (olive oil) by stomach tube at either 4 p.m. or 9 p.m. After 4 days of feeding, the rats were killed on the morning of the 5 th day in the postabsorptive state, i.e. $24 \mathrm{~h}$ after the last meal containing protein and either $\mathrm{I} 8-20 \mathrm{~h}$ or $\mathrm{I} 2-\mathrm{I} 4 \mathrm{~h}$ after being given the supplementary energy source, according to the time of its administration.

In the experiments on the in vitro uptake of $\left[{ }^{14} \mathrm{C}\right]$ glycine, the rats received either the basic protein-free or protein-containing diets in the morning. At each of these levels of protein intake, some of the animals were given no further food (low-calorie intake group) and others were given carbohydrate at 1o p.m. (high-calorie intake group). After 7 days on these diets, the rats were killed in the morning in the postabsorptive state. In addition, one group of rats on the low-calorie intake and one on the high-calorie intake were fed $2 \mathrm{~h}$ before death with $2 \mathrm{~g}$ casein, in order to examine the action of previous calorie intake on protein metabolism during active absorption of amino acids from the intestine.

Incubation of pieces of liver and diaphragm. The rats were killed by exsanguination under ether anaesthesia. Slices were prepared from the livers, the mechanical chopper described by McIlwain \& Buddle (1953) being used, and about $500 \mathrm{mg}$ of slices were added to each incubation flask. In the experiments on $\left.{ }^{35} \mathrm{~S}\right]$ methionine incorporation, the diaphragm was also dissected out from each animal, the central tendon removed and the remaining muscle added to a flask for incubation. The incubation flasks for both liver slices and diaphragm contained $4 \mathrm{ml}$ of the medium of Sinex, MacMullen \& Hastings (1952) to which was added either I $\mu \mathrm{c}\left[2{ }^{-14} \mathrm{C}\right]$ glycine or $2 \mu \mathrm{c}\left[{ }^{35} \mathrm{~S}\right]$ methionine. The flasks were then gassed with a mixture of $95 \% \mathrm{O}_{2}$ and $5 \% \mathrm{CO}_{2}$ and incubated at $37^{\circ}$. Throughout the experiment, sterility precautions were taken by heat treatment of all glassware and by passing the medium through a Seitz filter.

Isolation of protein from liver and diaphragm. To terminate incubation, $\mathrm{x} \cdot 5 \mathrm{ml}$ of $30 \%(\mathrm{w} / \mathrm{v})$ trichloroacetic acid (TCA) were added to the flasks containing the liver slices and the precipitate was treated by the procedure of Sinex et al. (1952). The pieces of muscle were removed from the flask and immersed in $0 \cdot 1 \mathrm{~N}-\mathrm{H}_{2} \mathrm{SO}_{4}$ to terminate metabolic reactions, rinsed in distilled water and homogenized in a blender with $15 \mathrm{ml} 0.4 \mathrm{~N}-\mathrm{NaOH}$ for $15 \mathrm{~min}$. The protein was then precipitated by addition of $30 \% \mathrm{TCA}$ and recovered by centrifugation.

The TCA precipitates obtained from liver and diaphragm were washed three times with $10 \%$ ice-cold TCA and then heated at $90^{\circ}$ for $15 \mathrm{~min}$ in $10 \%$ TCA to remove nucleic acids (Schneider, 1945 ). In the experiments with [ $\left.{ }^{35} \mathrm{~S}\right] \mathrm{methionine,} \mathrm{the} \mathrm{in-}$ soluble residue was dissolved in $0.4 \mathrm{~N}-\mathrm{NaOH}$, the solution reprecipitated with $30 \%$ TCA and the precipitate then separated by centrifugation. This procedure has been recommended by Melchior \& Halikis (1952) for the removal of free methionine trapped in the protein precipitate, and was carried out twice on each sample. When this procedure is used, tissue which had been inactivated with $30 \%$ TCA before addition of isotope to the flask (zero time control) did not show significant uptake of radioactivity by the tissue proteins. In the experiments with $\left[{ }^{14} \mathrm{C}\right]$ glycine, it was not found necessary to use the procedure of Melchior \& Halikis, since low zero time control 
values were obtained even when these steps were omitted. The adequacy of this shortened procedure is also demonstrated by the finding that uptake of $\left[{ }^{14} \mathrm{C}\right]$ glycine by liver-slice proteins isolated in this manner can be almost completely inhibited by addition of a nitrogen mustard to the incubation mixture (Clark, Goodlad \& Munro, I958). The precipitated protein was finally washed with $20 \mathrm{ml}$ portions of $95 \%$ ethanol, ethanol-chloroform $(3: 1)$, ethanol-diethyl ether $(3: 1)$, ethanol and finally diethyl ether, and allowed to dry in air.

Measurements of radioactivity of protein samples. These measurements were made by procedures described previously (Munro, Black \& Thomson, I959). With liver samples incubated with $\left[{ }^{14} \mathrm{C}\right]$ glycine, the protein preparations were counted without isolation of the amino acid, by spreading the finely ground protein on a Polythene planchet $\mathbf{I ~} \mathrm{cm}$ in diameter and counting at infinite thickness with an end-window Geiger-Müller tube. The activities have been expressed as counts per min per planchet. With tissues incubated with $\left.{ }^{35} \mathrm{~S}\right]$ methionine, the methionine $\mathrm{S}$ was isolated from an acid hydrolysate of the tissue protein and counted as benzidine sulphate with an endwindow Geiger-Müller tube, suitable corrections for self-absorption being applied. The activities have been expressed as counts per min per mg methionine S.

Measurement of the free glycine contents of liver. The amount of glycine in the free amino acid pools in the livers of animals killed after receiving the various diets was estimated as the dinitrophenyl derivative by the quantitative procedure of Krol (1952). Samples of liver were treated with 5 vol. of ice-cold Io $\%$ TCA and the precipitate was washed twice with $10 \%$ TCA. The supernatant fluid and washings were combined and the TCA was extracted with diethyl ether until the $\mathrm{pH}$ rose to 4 . The aqueous phase was then dried under reduced pressure, the residue taken up in a small volume of water and allowed to react with fluorodinitrobenzene to yield dinitrophenylglycine which was then recovered quantitatively by the procedure described by Krol (I952). This procedure has been shown by us to be satisfactory for separation of glycine from artificial mixtures of amino acids, from which essentially complete recovery of glycine was obtained.

\section{In vivo studies of labelled glycine uptake}

Animals and diets. Male albino rats of from 180 to $200 \mathrm{~g}$ body-weight were housed in separate cages and were given the protein-containing or protein-free diets used in the in vitro studies described above. In this experiment, however, the basic diets were given in the evening at levels of 0.8 times the amount stated on p. 245 because of the smaller size of rat used; the variable energy content was provided by changing the amount of carbohydrate given in the morning. For an initial training period of 7 days all the rats were given the basic protein-containing or protein-free diet with sufficient carbohydrate in the morning meal to maintain a calorie intake of $1200 \mathrm{kcal} / \mathrm{m}^{2}$. During the remaining 4 days of the experiment, carbohydrate intake was altered so that rats at each level of protein intake received either about $800 \mathrm{kcal} / \mathrm{m}^{2}$ or about $1600 \mathrm{kcal} / \mathrm{m}^{2}$. On the morning after the last day of feeding, the rats were in the postabsorptive state and were injected intramuscularly with $\left[2,-{ }^{14} \mathrm{C}\right]$ glycine ( $10 \mu \mathrm{c} /$ I $00 \mathrm{~g}$ body-weight). They were killed at intervals of 3,6 or $9 \mathrm{~h}$ after injection without further feeding. 
Determination of $\left[{ }^{14} \mathrm{C}\right]$ glycine incorporation by liver. The rats were killed by exsanguination under ether anaesthesia. The liver was perfused with $0.9 \%(\mathrm{w} / \mathrm{v}) \mathrm{NaCl}$ and then homogenized in cold $10 \%$ TCA. The supernatant fluid was retained for estimation of radioactivity in the free glycine fraction and the precipitate was washed twice with 10 \% TCA, and then extracted with lipid solvents as described by Munro \& Naismith (I953). The resultant dry powder was used for isolation of liver-protein glycine. Glycine was isolated from the free amino acid fraction and from the hydrolysed liver protein as the dinitrophenyl derivative, and its content of ${ }^{14} \mathrm{C}$ was measured by the procedures given in detail by Clark, Naismith \& Munro (1957). The activities have been expressed as counts/min $100 \mu \mathrm{g}$ glycine.

Determination of the protein content of the liver. The amount of protein in each liver was measured by the methods described by Munro \& Naismith (1953) and has been expressed as mg protein/loo g initial body-weight.

Determination of the glycine content of liver protein. In order to determine whether the various diets used in these experiments altered the glycine content of the mixed liver proteins, samples of liver were treated with cold 10\% TCA before extraction of nucleic acids with hot TCA (Schneider, 1945) and extraction of lipids with organic solvents, as described for the preparation of liver protein in the in vitro series of experiments. The $\mathrm{N}$ content of the dry residue was then measured (Munro \& Naismith, 1953) and a portion was hydrolysed for $16 \mathrm{~h}$ in $6 \mathrm{~N}-\mathrm{HCl}$ at $105^{\circ}$ and then subjected to the procedure of Krol (1952) for quantitative estimation of its glycine content.

\section{RESULTS}

\section{Diet and the in vitro uptake of labelled amino acids}

In the first series of experiments, only animals receiving an adequate intake of protein were studied. The rats were killed in the morning in the postabsorptive state, i.e. $24 \mathrm{~h}$ after the last meal containing protein and either $\mathrm{I} 2-\mathrm{I} 4 \mathrm{~h}$ or $\mathrm{I} 8-20 \mathrm{~h}$ after being given the supplementary energy source, according to the time of its administration. The effect of these two levels of calorie intake on the incorporation of $\left[{ }^{35} \mathrm{~S}\right]-$ methionine by the proteins of liver and diaphragm during a $\mathrm{I} h$ period of incubation is shown in Table I. Since no significant difference was observed between the actions of carbohydrate and fat as energy sources, they have not been differentiated in the calculations. As previous calorie intake rose, the incorporation of ${ }^{35} \mathrm{~S}$ into the proteins of both liver and diaphragm increased, the combined results for the two periods giving a highly significant difference due to calorie level $(P<0.01)$. It can thus be concluded that the calorie content of the diet continues to influence protein metabolism in liver and in diaphragm for at least $20 \mathrm{~h}$ after the last meal has been consumed.

These results were amplified by similar experiments with $\left[{ }^{14} \mathrm{C}\right]$ glycine in which the level of protein intake as well as of calorie intake was varied. The rats received either a protein-free diet or an adequate intake of protein, and at each protein level some were given a low calorie intake and others a high calorie intake; in addition, one group of rats on the low calorie intake and one on the high calorie intake were given casein $2 \mathrm{~h}$ before killing, in order to determine the effect of previous energy intake on amino acid 
incorporation by animals actively absorbing amino acids from the intestine. Table 2 shows the effects of these six dietary conditions on the uptake of $\left[{ }^{14} \mathrm{C}\right]$ glycine by liver protein during $\mathrm{I}$ and $2 \mathrm{~h}$ periods of incubation. Statistical evaluation of the results by analysis of variance showed that incorporation was significantly affected $(P<0 \cdot 0 \mathrm{I})$

Table 1 . Influence of prezious level of calorie intake on uptake of $\left[{ }^{35} S\right]$ methionine by the proteins of liver slices and of diaphragm during in vitro incubation

(Rats fed on a diet providing an adequate amount of protein at low and high levels of calorie intake were killed in the postabsorptive state, either $12-14 \mathrm{~h}$ or $18-20 \mathrm{~h}$ after the last meal. Slices of liver and pieces of diaphragm were incubated for $\mathrm{I} h$ with $\left[{ }^{35} \mathrm{~S}\right]$ methionine. The table shows the number of rats studied at each level of calorie intake. One incubation with liver slices and one with diaphragm was carried out per rat)

\begin{tabular}{|c|c|c|c|c|c|c|c|c|}
\hline \multirow{2}{*}{$\begin{array}{c}\text { Time } \\
\text { elapsed } \\
\text { since } \\
\text { last meal } \\
\text { (h) }\end{array}$} & \multicolumn{4}{|c|}{$\begin{array}{l}\text { Specific activity of liver protein } \\
\text { (counts/min mg methionine } \mathrm{S} \text { ) }\end{array}$} & \multicolumn{4}{|c|}{$\begin{array}{l}\text { Specific activity of diaphragm protein } \\
\text { (counts/min } \mathrm{mg} \text { methionine } \mathrm{S} \text { ) }\end{array}$} \\
\hline & $\begin{array}{l}\text { No. } \\
\text { of } \\
\text { rats }\end{array}$ & $\begin{array}{l}\text { Low } \\
\text { calorie } \\
\text { intake }\end{array}$ & $\begin{array}{l}\text { High } \\
\text { calorie } \\
\text { intake }\end{array}$ & Difference & $\begin{array}{l}\text { No. } \\
\text { of } \\
\text { rats }\end{array}$ & $\begin{array}{l}\text { Low } \\
\text { calorie } \\
\text { intake }\end{array}$ & $\begin{array}{l}\text { High } \\
\text { calorie } \\
\text { intake }\end{array}$ & Difference \\
\hline $12-14$ & 7 & 2517 & 3094 & +577 & 6 & 429 & $5 \mathrm{II}$ & $+8 z$ \\
\hline $18-20$ & I I & 1514 & 2223 & +709 & 12 & 384 & 574 & $+I 90$ \\
\hline $\begin{array}{l}\text { Combined } \\
\text { values }\end{array}$ & 18 & 1872 & 2530 & $+65^{8} \pm \mathrm{x}_{5} 3^{*}$ & 18 & 398 & 552 & $+I_{54 \pm 42 *}$ \\
\hline
\end{tabular}

* Mean value with its standard error; by the $t$ test, the difference is significant $\left(P<0^{\circ} \circ \mathrm{r}\right)$.

\section{Table 2. Influence of protein and calorie content of the diet on the uptake of $\left[{ }^{14} \mathrm{C}\right]$ glycine by the protein of liver slices during in vitro incubation}

(Rats fed on a protein-free or protein-containing diet at low or high levels of calorie intake were killed either in the postabsorptive state or $2 \mathrm{~h}$ after a meal of casein. The liver slices were incubated for I or $2 \mathrm{~h}$ with $\left[2-{ }^{14} \mathrm{C}\right]$ glycine. Each entry is the mean value for four rats)

\begin{tabular}{|c|c|c|c|c|c|}
\hline \multirow[b]{2}{*}{ Diet } & \multirow[b]{2}{*}{ State when killed } & \multirow[b]{2}{*}{$\begin{array}{c}\text { Duration } \\
\text { of } \\
\text { incubation }\end{array}$} & \multicolumn{3}{|c|}{$\begin{array}{l}\text { Specific activity of liver protein } \\
\text { (counts/min planchet) }\end{array}$} \\
\hline & & & $\begin{array}{l}\text { Low } \\
\text { calorie } \\
\text { intake }\end{array}$ & $\begin{array}{l}\text { High } \\
\text { calorie } \\
\text { intake }\end{array}$ & Difference \\
\hline Protein-free & Postabsorptive & $\begin{array}{l}\mathbf{1} \\
2\end{array}$ & $\begin{array}{l}230 \\
569\end{array}$ & $\begin{array}{l}430 \\
838\end{array}$ & $\begin{array}{l}+200 \\
+269\end{array}$ \\
\hline With adequate protein & Postabsorptive & $\begin{array}{l}\mathbf{1} \\
2\end{array}$ & $\begin{array}{l}496 \\
948\end{array}$ & $\begin{array}{r}752 \\
1396\end{array}$ & $\begin{array}{l}+256 \\
+448\end{array}$ \\
\hline With adequate protein & After a meal of casein & $\begin{array}{l}\mathbf{I} \\
2\end{array}$ & $\begin{array}{l}263 \\
552\end{array}$ & $\begin{array}{r}629 \\
1007\end{array}$ & $\begin{array}{l}+366 \\
+455\end{array}$ \\
\hline
\end{tabular}

Analysis of variance showed that incorporation of glycine was significantly affected $(P<0.01)$ by time of incubation, protein intake and calorie level of the diet without significant interactions.

by time of incubation, by previous calorie intake and by previous protein intake, without significant interaction between these three factors. Thus, irrespective of whether the diet was free from protein or contained protein, or whether the animals were in the postabsorptive state or were actively absorbing amino acids at the time of death, more radioactivity was deposited in the proteins of the liver slices when the preceding diet provided a high level of calorie intake. 
This finding does not necessarily mean that more protein was synthesized by liver slices prepared from these animals. Differences in the apparent uptake of $\left[{ }^{14} \mathrm{C}\right]$ glycine by tissue protein can also occur because of changes in the radioactivity of the free glycine pool from which the protein is synthesized. Thus if the diet causes the free glycine content of the tissue to decrease, the labelled glycine added in the medium will undergo less dilution and in consequence the number of labelled molecules incorporated into the tissue protein will be increased. Measurement of the free glycine content of the livers of rats receiving the different diets shows (Table 3 ) that the highest concentration of free glycine occurred in the livers of rats on the protein-free diet, which may partly account for the lower levels of incorporation observed after this diet (Table 2). However, addition of calories to the different diets did not reduce the free glycine content of the liver at either level of protein intake and in consequence the greater labelling of protein observed in the livers of animals on the higher calorie intakes cannot be ascribed to less dilution of the labelled molecules by unlabelled glycine.

\section{Table 3. Free glycine concentration in the livers of rats fed on diets providing different amounts of protein and calories}

('The rats were fed under the same conditions as those described in Table 2. Each entry is the mean value with its standard error for four rats)

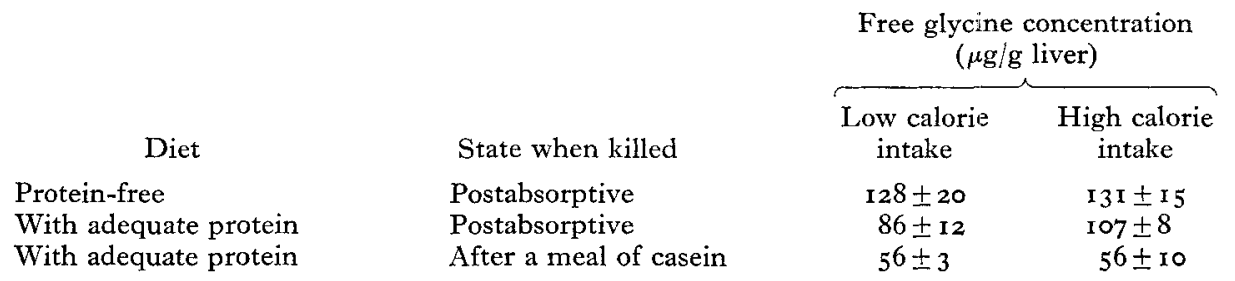

Analysis of variance showed that free glycine concentration was significantly affected by the protein content of the diet $(P<0.01)$ but not by the calorie level $(P>0.05)$.

A second way in which diet could influence the labelling of the free amino acid pool is by affecting the rate of penetration of the labelled amino acid into the tissue from the medium. Thus dietary treatments which result in more rapid passage of the labelled amino acid into the intracellular pool will lead to earlier labelling of the tissue protein but, once the concentration of isotope in the free amino acid pool of the tissue has reached equilibrium, continuation of incubation will not lead to any further increase in labelling. Table 2 shows that the extra radioactivity in the liver proteins observed in the high-calorie intake groups was not significantly increased by continuing incubation from $\mathrm{I}$ to $2 \mathrm{~h}$ (no interaction between the action of calorie intake and time of incubation), which suggests that the influence of the calorie content of the diet was restricted to the initial stages of incubation, and was due to an increase in the rate at which the $\left[{ }^{14} \mathrm{C}\right]$ glycine penetrated the liver slices.

From these studies on incorporation of $\left.{ }^{35} \mathrm{~S}\right]$ methionine and $\left[{ }^{14} \mathrm{C}\right]$ glycine into tissue slices, it is apparent that the energy content of the diet has an effect on protein metabolism which persists for at least $20 \mathrm{~h}$ after the last meal, but the experiments with $\left[{ }^{4} \mathrm{C}\right]$ glycine show that changes in the uptake of the labelled amino acid by the 
tissue proteins can result from several causes. The main effect of previous calorie intake seems to be confined to the initial incorporation of isotope and may represent more rapid penetration of the labelled amino acid into the intracellular pool. Under these circumstances, it is difficult to assess whether a real stimulus to protein biosynthesis was taking place as the result of a previous high calorie intake. For this reason, in vivo experiments were conducted in which the radioactivity of glycine in the free amino acid pool of liver was measured and the uptake of $\left[{ }^{14} \mathrm{C}\right]$ glycine by the liver proteins was computed in relation to the activity of the free glycine pool at various time intervals after injection.

\section{Diet and the in vivo uptake of labelled glycine}

In these experiments the same diets were used as in the in vitro studies but the order of feeding with the dietary components was reversed, the variable energy source being taken in the morning meal and the basic protein-free or protein-containing diet in the evening. The animals were injected with $\left[{ }^{14} \mathrm{C}\right]$ glycine at $9 \mathrm{a} . \mathrm{m}$. on the day following the final day of feeding, some $24 \mathrm{~h}$ after the last meal in which the calorie intake was varied. The information obtained from rats killed at 3,6 and $9 \mathrm{~h}$ after injection is given in Table 4. It is apparent that the specific activity of glycine in the

\section{Table 4. Influence of diet on the in vivo uptake of $\left[{ }^{14} \mathrm{C}\right]$ glycine by the free amino acid pool and protein of liver}

(Rats fed on protein-free or protein-containing diets at two levels of calorie intake were injected with [2-14 C]glycine in the postabsorptive state and killed 3,6 or 9 h thereafter without further feeding. Each entry is the mean value for two rats)

\begin{tabular}{|c|c|c|c|c|c|c|c|}
\hline & & $\begin{array}{r}\text { Specif } \\
\text { fre } \\
\text { (count }\end{array}$ & $\begin{array}{l}\text { vity of } \\
\text { ine } \\
\text { Ioo } \mu \mathrm{g})\end{array}$ & $\begin{array}{l}\text { Specif } \\
\text { prot } \\
\text { (counts }\end{array}$ & $\begin{array}{l}\text { ivity of } \\
\text { ycine } \\
\text { I oo } \mu \mathrm{g})\end{array}$ & $\begin{array}{r}\text { Live } \\
(\mathrm{mg} \\
\text { initial b }\end{array}$ & $\begin{array}{l}\text { otein } \\
\text { (0o g } \\
\text {-weight) }\end{array}$ \\
\hline Diet & $\begin{array}{c}\text { after } \\
\text { injection } \\
\text { (h) }\end{array}$ & $\begin{array}{l}\text { Low } \\
\text { calorie } \\
\text { intake }\end{array}$ & $\begin{array}{c}\text { High } \\
\text { calorie } \\
\text { intake }\end{array}$ & $\begin{array}{c}\text { Low } \\
\text { calorie } \\
\text { intake }\end{array}$ & $\begin{array}{l}\text { High } \\
\text { calorie } \\
\text { intake }\end{array}$ & $\begin{array}{c}\text { Low } \\
\text { calorie } \\
\text { intake }\end{array}$ & $\begin{array}{l}\text { High } \\
\text { calorie } \\
\text { intake }\end{array}$ \\
\hline Protein-free & $\begin{array}{l}3 \\
6 \\
9\end{array}$ & $\begin{array}{r}2362 \\
1523 \\
875\end{array}$ & $\begin{array}{r}2188 \\
1332 \\
716\end{array}$ & $\begin{array}{l}294 \\
361 \\
331\end{array}$ & $\begin{array}{l}355 \\
37 \text { I } \\
349\end{array}$ & $\begin{array}{l}55 \\
57 \\
55\end{array}$ & $\begin{array}{l}50 \\
48 \\
54\end{array}$ \\
\hline $\begin{array}{l}\text { With adequate } \\
\text { protein }\end{array}$ & $\begin{array}{l}3 \\
6 \\
9\end{array}$ & $\begin{array}{r}1825 \\
\mathrm{I} 173 \\
733\end{array}$ & $\begin{array}{r}\text { I } 490 \\
945 \\
717\end{array}$ & $\begin{array}{l}219 \\
229 \\
220\end{array}$ & $\begin{array}{l}216 \\
207 \\
206\end{array}$ & $\begin{array}{l}70 \\
70 \\
69\end{array}$ & $\begin{array}{l}84 \\
81 \\
82\end{array}$ \\
\hline
\end{tabular}

free amino acid pool was influenced to an important extent by the diet previously administered, and allowance must be made for this influence in assessing the effect of diet on $\left[{ }^{14} \mathrm{C}\right]$ glycine incorporation into liver protein. Because of the limited number of time intervals at which radioactivity measurements were made, it was not possible to undertake a rigorous kinetic study of the turnover time of liver protein such as that used by Henriques, Henriques \& Neuberger (1955). Accordingly, a simpler approach was adopted in which allowance for the different activities in the free glycine pool was made by calculating the total relative activities of the liver protein samples (Campbell, Olley \& Blewett, I949). At each time interval, the specific activity of the liver-protein 
glycine was expressed as a percentage of the specific activity of the corresponding free glycine, to make allowance for differences in the activities of the precursor pools of different animals. It was then necessary to adjust these figures to include a measure of the total amount of protein in which incorporation was taking place; thus an animal with a high relative specific activity and a small amount of liver protein might not be synthesizing a greater number of new molecules than an animal with a low relative specific activity but having a larger amount of protein in its liver. As a measure of the absolute rate of replacement per liver, the relative specific activities were therefore multiplied by the total amounts of protein N/100 $\mathrm{g}$ initial body-weight, the
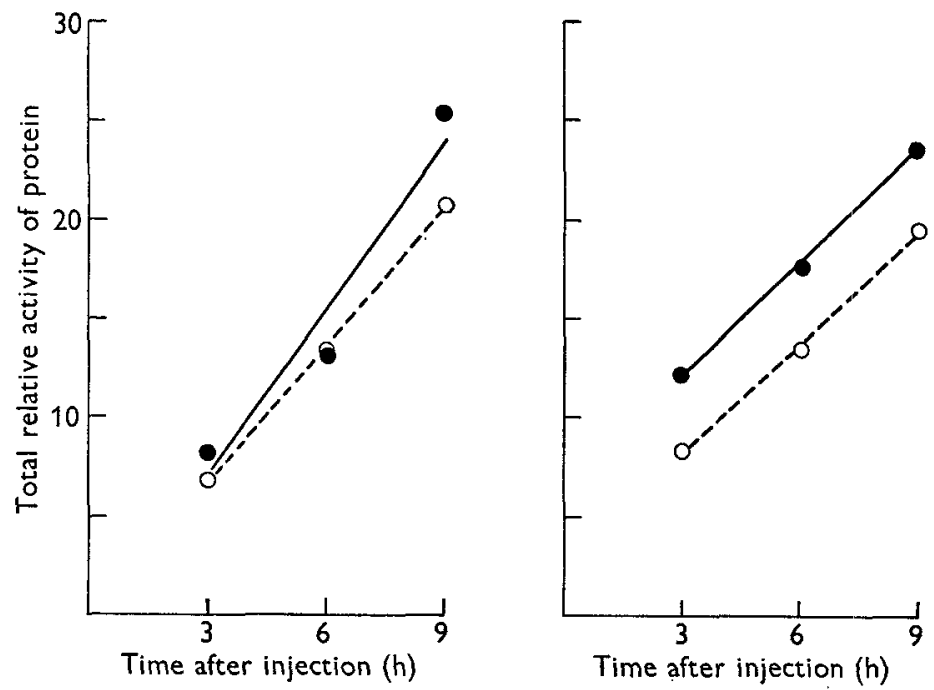

Fig. I. In vivo incorporation of radioactivity into liver protein at different times after injection of $\left[2-^{14} \mathrm{C}\right]$ glycine. At the time of injection, the rats were in the postabsorptive state, having received either a low level of calorie intake $(0---0)$ or a high level of calorie intake ( - $\bullet$ ). The left-hand graph represents animals on a protein-free diet, the right-hand graph animals on an adequate protein intake. The results are expressed as total relative activities, computed on an arbitrary scale from the values given in Table 4 . Each point represents the mean result for two animals. Analysis of variance showed that previous calorie intake was without effect on incorporation in animals on the protein-free diet $(P>0.05)$, but had a significant action on incorporation when the diet contained protein $(P<0.02)$.

products being referred to as total relative activities. This final computation was based on the assumption that the percentage of glycine in the mixed liver proteins was not significantly affected by the various dietary treatments. Direct estimation of the glycine content of the mixed proteins of the liver was carried out on samples taken from three animals on each of the four diets. The glycine contents were found to be $5.0 \pm 0.07 \%$ and $5.1 \pm 0.09 \%$ respectively for rats receiving the low calorie and high calorie levels of the protein-free diet; at the adequate level of protein intake, the lowcalorie and high-calorie intake groups had $5 \cdot \mathrm{I} \pm 0.09 \%$ and $5.5 \pm 0.15 \%$ glycine respectively in their liver proteins. Differences in amino acid composition of this order of magnitude are not an important source of error in computing the total uptake of $\left[{ }^{4} \mathrm{C}\right]$ glycine by protein. 
The total relative activities of liver protein for these four dietary groups are shown in Fig. I. With increasing time after injection of $\left[{ }^{14} \mathrm{C}\right]$ glycine, there was a linear increment in total relative activity. Analysis of variance of the values showed that, with the protein-free diet, the values obtained for the low-calorie and the high-calorie intake groups did not differ significantly $(P>0.05)$; with animals receiving an adequate intake of protein, however, there was a significantly greater incorporation of $\left[{ }^{14} \mathrm{C}\right]-$ glycine when the calorie content of the diet was raised $(P<0.02)$. It can thus be concluded that, even in the postabsorptive state, the calorie content of the diet continues to influence the synthesis of liver protein in animals receiving an adequate protein intake but not in animals on a protein-free diet.

\section{DISCUSSION}

There is extensive published evidence to show that protein metabolism is influenced by the calorie content of the diet (see review by Munro, 1951), the relationship being affected by the amount of protein in the diet. With rats, Munro \& Naismith (1953) found that there was an improvement in $\mathrm{N}$ balance and in deposition of protein in the liver when calories were added to a diet containing an adequate amount of protein, but not when they were added to a protein-free diet. In the experiments described here, it was found that calorie intake affected the in vivo incorporation of $\left[{ }^{14} \mathrm{C}\right]$ glycine into liver protein when the diet contained adequate amounts of protein but not when it was protein-free. It would thus appear that the failure of protein metabolism to respond to increased calorie intake on a protein-free diet is due to the limitation on the rate of protein synthesis imposed by such a diet.

These experiments, and also the in vitro studies on amino acid incorporation, show that the effect of calorie intake on protein metabolism is still considerable when some $20 \mathrm{~h}$ have elapsed after the last meal. This persistence of the influence of the calorie content of the diet into the postabsorptive phase is in agreement with other evidence of long-term effects of calorie level on the course of protein metabolism. Thus the addition of energy to the diets of human subjects (Cuthbertson \& Munro, 1937) and of dogs (Munro \& Wikramanayake, 1954) caused $\mathrm{N}$ retention which continued for several days after the source of extra energy had been withdrawn.

It is apparent from these findings that calorie intake can influence the course of protein metabolism at times other than the immediate phase of amino acid absorption after a meal of protein. Evidence of its effects on protein synthesis during active absorption was not obtained during the series of in vivo experiments described here. However, utilization of dietary protein, as judged by the $\mathrm{N}$ balance index, is not altered until calorie intake has fallen below $50 \%$ of the animal's energy requirements (Allison \& Anderson, 1945). This means, that, although $\mathrm{N}$ balance becomes less favourable as calorie intake is reduced, addition of a given amount of protein to the diet still results in the same improvement in $\mathrm{N}$ balance at the different levels of calorie intake. In a similar manner, Campbell \& Kosterlitz (1948) observed that changes in protein intake had the same effect on the non-glycogen, non-lipid solids (protein, nucleic acids and phospholipid) of the liver at several levels of calorie intake. 
From these studies it would seem that the ability of absorbed protein $\mathrm{N}$ to cause $\mathrm{N}$ retention and to deposit solid matter in the liver is not impaired by a moderate reduction in energy intake. It is thus possible that energy intake has its main effect on amino acid utilization during the postabsorptive phase between meals. This conclusion would be in accord with the finding (Munro \& Wikramanayake, I954) that addition of extra calories to the diet causes the same degree of $\mathrm{N}$ retention whether it is given with the protein of the diet or $12 \mathrm{~h}$ apart from it.

\section{SUMIMAR Y}

I. Slices of liver and diaphragm were obtained from rats fasting for $12-20 \mathrm{~h}$ after receiving diets of different calorie content. When they were incubated with [ $\left.{ }^{35} \mathrm{~S}\right]-$ methionine for $\mathrm{I} h$, the uptake of methionine by the tissue protein was found to be considerably increased when the preceding diet provided a high level of energy.

2. Similar experiments with liver slices incubated in a medium containing $\left[{ }^{44} \mathrm{C}\right]$ glycine showed that this effect of calorie level in the diet was not altered by using a preparatory protein-free diet or by giving a protein meal just before killing the animals. Since the influence of calorie level on uptake of $\left[{ }^{14} \mathrm{C}\right] \mathrm{glycine}$ was confined to the initial period of incubation and was not increased by further incubation, it is suggested that the phenomenon represents an increase in the rate of penetration of the labelled amino acid into the free amino acid pool within the tissue slice. This possibility makes it difficult to recognize authentic changes in rate of protein synthesis by tissue slices.

3. The influence of calorie intake on the transfer of $\left[{ }^{14} \mathrm{C}\right]$ glycine from the free amino acid pool of liver to liver protein was studied by injecting rats in the postabsorptive state with $\left[{ }^{14} \mathrm{C}\right]$ glycine and measuring the activities of glycine in the free amino acid pool and in the tissue protein at different time intervals thereafter. With diets containing adequate amounts of protein, a high calorie level in the diet caused an increase in the total amount of glycine taken up by liver protein, but with proteinfree diets the calorie level provided in the diet did not influence incorporation.

4. It is suggested from these results and from a study of the evidence published in the literature that the major effect of the calorie content of the diet in influencing protein metabolism is on the utilization of circulating amino acids between meals, and not during the active phase of absorption of amino acids after meals.

We acknowledge with thanks provision of scholarships for training in research methods from the Medical Research Council to two of us (J.C. and D.J.N.). The cost of isotopes was defrayed by a grant from the Advisory Council for Medical Research of the Department of Health for Scotland, for which we are grateful. 


\section{REFERENCES}

Allison, J. B. \& Anderson, J. A. (1945). F. Nutr. 29, 413.

Campbell, I. G., Olley, J. \& Blewett, M. (I949). Biochem. F. 45, 105.

Campbell, R. M. \& Kosterlitz, H. W. (1948). F. Physiol. 107, 383.

Clark, C. M., Goodlad, G. A. J. \& Munro, H. N. (1958). Biochem. Pharmacol. r, 213.

Clark, C. M., Naismith, D. J. \& Munro, H. N. (r957). Biochim. biophys. Acta, 23, 587.

Cuthbertson, D. P. \& Munro, H. N. (1937). Biochem. F. 31, 694.

Henriques, O. B., Henriques, S. B. \& Neuberger, A. (1955). Biochem. F. 60, 409.

Krol, S. (1952). Biochem. F. 52, 227.

McIlwain, H. \& Buddle, H. L. (1953). Biochem. F. 53, 412.

Melchior, J. B. \& Halikis, M. N. (1952). F. biol. Chem. 199, 773.

Munro, H. N. (1949). I. Nutr. 39, 375.

Munro, H. N. (i95 I). Physiol. Rev. 31, 449.

Munro, H. N., Black, J. G. \& Thomson, W. S. T. (1959). Brit. F. Nutr. r3, 475.

Munro, H. N. \& Naismith, D. J. (1953). Biochem. F. 54, I9I.

Munro, H. N. \& Wikramanayake, T. W. (1954). F. Nutr. 52, 99.

Schneider, W. C. (1945). F. biol. Chem. r6r, 293.

Sinex, F. M., MacMullen, J. \& Hastings, A. B. (1952). F. biol. Chem. 198, 6 1 5. 